E3S Web of Conferences 1, 13010 (2013)

DOI: $10.1051 / \mathrm{e} 3$ sconf/20130113010

(c) Owned by the authors, published by EDP Sciences, 2013

\title{
Removal of Lead from aqueous phase using Amberlite and natural Zeolite
}

\author{
S. H. Tabatabaei $^{1}$, M. Asemanrafat ${ }^{2}$ and M. Nousahdi ${ }^{3}$ \\ ${ }^{1}$ Associate Professor, Department of Water Engineering, Faculty of Agriculture, Shahrekord University, Shahrekord, \\ Iran. corresponding author: stabaei@agr.sku.ac.ir \\ ${ }^{2}$ Former M.Sc. Student, Water Engineering, Faculty of Agriculture, Shahrekord University, Shahrekord, Iran \\ ma_aseman1360@yahoo.com \\ ${ }^{3}$ Associate Professor, Department of Water Engineering, Faculty of Agriculture, Shiraz University, Shiraz, Iran. \\ noshadi@shirazu.ac.ir
}

\begin{abstract}
Two following reason lead $(\mathrm{Pb})$ us to find a way for removing heavy metals (HM) from the water resources, first limitation of water resource and increasing of water scarcity and second increaseing of surface and groundwater contamination by HM, (derived from industrial and municipal wastewater). In this research, Zeolite (Clinoptilolit) as natural and Amberlite (IR-120) as chemical were used as sorbents of Pb. Experiments were done in batch mode under various operational conditions including three size of zeolite and one mean diameter of Amberlite. An splite-plot experimental design was employed with 60 treatments and three replications at Shiraz University, Shiraz, Iran in 2011. The treatment were five different concentration of the $\mathrm{Pb}$ contamination and three size of zeolite $(0.075,0.2$ and $0.42 \mathrm{~mm})$. The concentration for Pb were: $40,250,500$, 1000. The removing efficiency of the zeolite and Amberlite was measured for $\mathrm{Pb}$. The results showed that the effect of concentration of contamination and zeolite size were statisticaly significant. It showed that by increasing of the concentration of contamination, absorption of the HM increases linearly by zeolite. Maximum $\mathrm{Pb}$ absorption occurred at $1250 \mathrm{mg} / \mathrm{l}$ with a value of $59.97 \mathrm{mg}$ for 1 grams of zeolite. The minimum $\mathrm{Pb}$ absorption occurred at $40 \mathrm{mg} / \mathrm{l}$ with a value of $1.82 \mathrm{mg}$ for 1 grams of zeolite. The results showed that the effect of concentration of $\mathrm{HM}$ were statisticaly significant for Amberlite and it also observed that the absorption of $\mathrm{HM}$ by Amberlite increases linearly. Maximum $\mathrm{Pb}$ absorption occurred at $1250 \mathrm{mg} / \mathrm{l}$ with a value of $62.35 \mathrm{mg}$ for 1 grams of Amberlite. The minimum $\mathrm{Pb}$ absorption occurred at $40 \mathrm{mg} / \mathrm{l}$ with a value of 1.98 mg for 1 grams of zeolite.
\end{abstract}

Key words: Absorption, Heavy metal, Amberlite and Zeolite

\section{Introduction}

One of the environmental issues is the existence of heavy metals (HM) in the wastewater and its effect on agricultural soils and cultivated plants in areas irrigated with such water. It can harmfully result in the accumulation of metals like Lead, Nickel and Cadmium in the soil. In Taiwan, most of the agricultural lands irrigated with industrial effluents have been contaminated and unusable. Also, more than $40 \%$ of the rivers in this country have been contaminated (Rahmani and Ghandi 2005). Therefore, to reuse urban effluents, industrial wastewater and the latex of the factories HM and other contaminant should be removed before irrigation (Mobtaker et al, 2005).
Using superabsorbant is a way of reducing heavy metals in wastewater (Kabiri, 2010). One of the ways of removing or reducing the contamination of wastewater is to use ion exchange resins (Wadu and Okamura, 1998). The adsorption of copper by the cationic resin of Amberlite IR-120 in concentrations of $0.3,0.5$ and $0.7 \mathrm{~g}$ $\mathrm{L}^{-1}$ was investigated by Kumarjha et al (2009). The absorption of $\mathrm{Pb}$ and $\mathrm{Cu}$ using PS-EDTA cationic resin was investigated by Liyuan et al. (2010). In low concentration, the more the capacity of ion, the more absorption will occur to the resin. Even for the ions with similar capacity, the heavier the molecular weight of ion, the more absorption will occure (Chalkesh. Amiri, 2002). Absorption of Boron by Amberlite was studied by Demircivi and Saygili (2008). 
The removal performance Linde $4 \mathrm{~A}$ zeolite ( $\mathrm{Na}$ form) on some $\mathrm{HM}$ ions $\left(\mathrm{Co}^{2+}, \mathrm{Cu}^{2+}\right.$ and $\left.\mathrm{Mn}^{2+}\right)$ in aqueous solutions was investigated by Rashad, et al. (2012). The adsorption of the studied HM metals was strongly dependent on $\mathrm{pH}$, temperature and zeolite dose. The optimum $\mathrm{pH}$ for the studied metals was found out to be 6.5 . The sorption rate of metal ions could be significantly improved by increasing $\mathrm{pH}$ value.

Therefor, cationic resins of Amberlite and Zeolite are a suitable as a source with a good efficiency for water and waste water treatment. In this research. the effect of Amberlite cationic resins and zeolite in reducing of Lead from an aqueous solution is investigated.

\section{Materials and Methods}

Cationic resins of sodiumic Amberlite IR-120 of Merck was used with $0.5 \mathrm{~mm}$ mean diameter. The zeolite used in this study was provided from the mine of Semnan and was milled in soil mechanics laboratory of Shiraz University and screened with successive sieves (Table 1). Zeolites with $0.075,0.200$ and $0.425 \mathrm{~mm}$ diameter were prepared for this research.

A specific amount of the salt of $\mathrm{Pb}$ was dissolved in a specific volume of distilled water to achieve the preferred concentration. Then 2 gr of zeolite Clionoptilolit with $0.425 \mathrm{~mm}$ diameter in $100 \mathrm{ml}$ was dissolved and the solution phase was shaken for 90 minutes. The solution phase was separated from the solid phase using filter paper and the concentration of solution phase was determined using atomic absorption. This procedure was repeated for 2 gr of Amberlite. According to the studies conducted by Tabatabaei and Light (2004), Demirbas, et al. (2005), Hui, et al.(2005) and Sprynskyy (2009), the major absorbtion were occurred in contact time of $90 \mathrm{~min}$. Therefore, the contact time of $90 \mathrm{~min}$ was considered. The amount of adsorption was calculated by Eq 1:

$$
\mathrm{AR}=\left(\mathrm{C}_{2}-\mathrm{C}_{1}\right) /(\mathrm{w})
$$

Where AR is the amount of absorption of HM in the unit of the weight of the absorptive, $\mathrm{C}_{1}$ is the primary concentration of absorptive $\left(\mathrm{mg} \mathrm{L}^{-1}\right), \mathrm{C}_{2}$ is the secondory of concentration absorptive $\left(\mathrm{mg} \mathrm{L}^{-1}\right)$, and $\mathrm{W}$ is the weight of absorptive (gr). For $\mathrm{Pb}$ pollutant, concentrations of $40,250,500,1000$ were selected. The above concentration of aqueous solutions were in contact with Amberlite cation resin and Zeolite, The removal efficiencies were determined.

\section{Result and Discussion}

\section{Zeolite Absorption}

The statistical analysis of the effects of different concentration of $\mathrm{Pb}$ aqueous solution and the effect of different size of Zeolite on the removal efficiency are showed in Table 2. According to Table 2, the effect of the variance concentration of the aqueous solution and different size of Zeolite on the absorption of $\mathrm{Pb}$ by Zeolite is significant $(p<0.01)$. Also the effect of error on the experiment was not significant: therefore the results are acceptable.

The results of Duncan's test showed that different Zeolite absorptions occurred in different $\mathrm{Pb}$ concentrations and that different sizes of Zeolite were significant at $1 \%$ level of probability (Table 2). Fig 1 shows the effect of different $\mathrm{Pb}$ concentrations on the absorption by Zeolite. According to Fig 1, maximum $\mathrm{Pb}$ absorption occurred at concentration of $1250 \mathrm{mg} \mathrm{L}^{-1}$ with a value of $59.98 \mathrm{mgg}^{-1}$, whereas minimum absorption was occurred at $40 \mathrm{mg} \mathrm{L}^{-1}$ with a value of $1.815 \mathrm{mgg}^{-1}$.

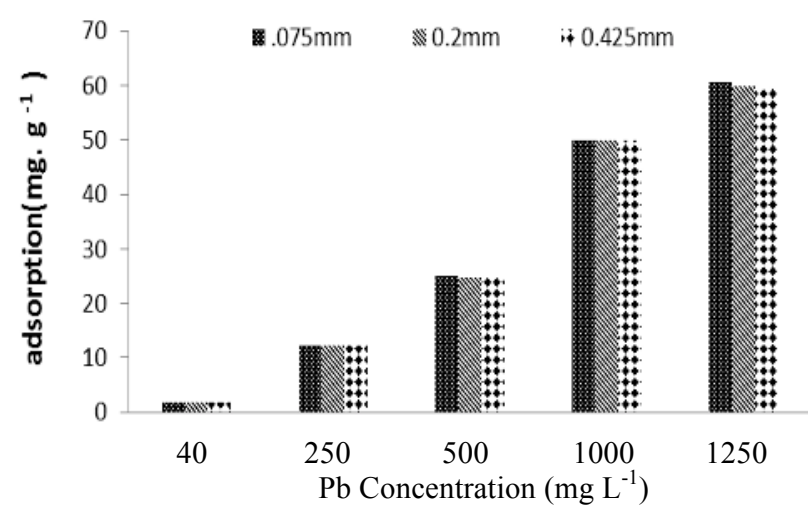

Fig. 1. The effect of different concentration of $\mathrm{Pb}$ on the absorption of Zeolite

Table 1. Chemical properties of zeolite (Afrand-Tooska company, 2007)

\begin{tabular}{|l|l|l|l|l|l|l|l|l|l|l}
\hline \multirow{2}{*}{$\begin{array}{l}\text { Location } \\
\text { Semnan }\end{array}$} & $\mathrm{SiO}_{2}$ & $\mathrm{Al}_{2} \mathrm{O}_{3}$ & $\mathrm{CaO}$ & $\mathrm{K}_{2} \mathrm{O}$ & $\mathrm{Na}_{2} \mathrm{O}$ & $\mathrm{Fe}_{2} \mathrm{O}_{3}$ & $\mathrm{MgO}$ & $\mathrm{TiO}_{2}$ & $\mathrm{P}_{2} \mathrm{O}_{5}$ & LOI \\
\cline { 2 - 10 } & 66.5 & 11.8 & 1.3 & 2.1 & 2 & 1.3 & 0.8 & 0.3 & 0.01 & 12 \\
\hline
\end{tabular}

Table 2. Analysis of variance of the removal efficiency of $\mathrm{Pb}, \mathrm{Ni}$ and $\mathrm{Cd}$ by Zeolite and Amberlite

\begin{tabular}{|l|l|l|l|l|l|l|l|l}
\hline & \multicolumn{3}{|c|}{ Zeolite } & \multicolumn{3}{|c}{ Amberlite } \\
\cline { 2 - 9 } & df & Mean & F & P & df & Mean & F & P \\
\hline Conc.of Pb & 4 & 5477 & $851597^{* *}$ & 0.00 & 4 & 1920.63 & $1048042^{* *}$ & 0.00 \\
\hline Adverse effect & 8 & 0.10 & $15 * *$ & 0.00 & & & & \\
\hline Size of Zeolite & 2 & 0.24 & $37^{* *}$ & 0.00 & & & & \\
\hline Error & 30 & 0.01 & & & 10 & 0.00183 & & \\
\hline
\end{tabular}


Amberlite Absorption

The statistical analysis of the effects of different concentrations of $\mathrm{Pb}$ aqueous solution on the removal efficiency are showed in Table 2. According to Table 2, the effect of the concentration of the aqueous solution on the absorbed $\mathrm{Pb}$ by Amberlite is significant $(\mathrm{p}<0.01)$. Also the effective of error on the experiments was not significant: therefore the results are acceptable.

The results of Duncan's test showed that different Amberlite absorptions occurred in different $\mathrm{Pb}$ concentrations of Amberlite was significant at $1 \%$ level of probability (Table 2). Fig 2 shows the effect of different $\mathrm{Pb}$ concentrations on the absorption by Amberlite. According to this Fig maximum $\mathrm{Pb}$ absorption occurred at concentration of $1250 \mathrm{mgL}^{-1}$ with a value of $62.35 \mathrm{mgg}^{-1}$,whereas minimum absorption was occurred at $40 \mathrm{mgL}^{-1}$ with a value of $1.97 \mathrm{mgg}^{-1}$ (Fig 2). The sorption capacity of the Amberlite IR-120 resin for $\mathrm{Pb}$ were was also evaluated by Demirbas et al. (2005). They showed that the maximum adsorption capacity of the resin was 19.6, 235.3 and $201.1 \mathrm{mmol} / \mathrm{g}$ for $\mathrm{Pb}, \mathrm{Ni}$ and $\mathrm{Cd}$, respectively.

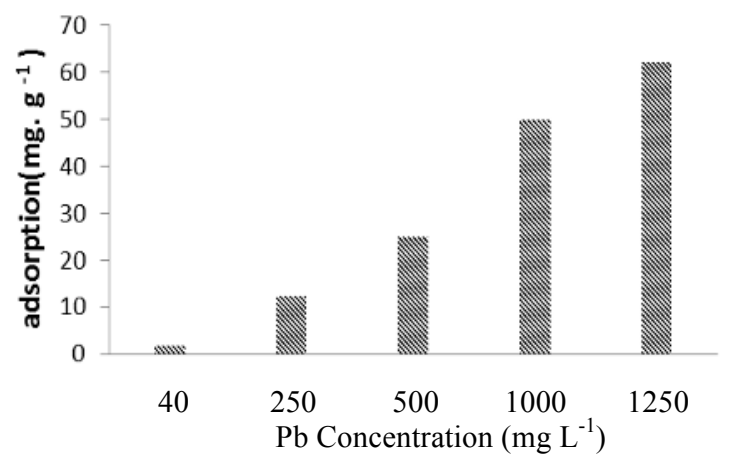

Fig. 2. The effect of different concentration of $\mathrm{pb}$ on the absorption of Amberlite

\section{Comparing Amberlite to Zeolite}

The absorption of $\mathrm{Pd}, \mathrm{Ni}$ and $\mathrm{Cd}$ in Amberlite (mean diameter $0.5 \mathrm{~mm}$ ) and Zeolite (mean diameter 0.425 $\mathrm{mm}$ ) was compared in Figure 3. According to Figure 3 the absorption of $\mathrm{Pb}, \mathrm{Ni}$ and $\mathrm{Cd}$ in Amberlite were more than Zeolite. The absorption of $\mathrm{pb}$ by Amberlite were 9.9, 2.2, 0.97, 0.06, 4.3, 3.61\% more than Zeolite in 40, 250, 500, 1000 and $1250 \mathrm{mg} \mathrm{L}^{-1}$, respectively.

The absorption of Ni by Amberlite were 10.36, 3.14, 3.86,0.94, $0.74 \%$ more than Zeolite in 4, 6, 15, 20 and $40 \mathrm{mg} \mathrm{L}^{-1}$, respectively and for Cd the absorption of Amberlite were 3.76, 5.52, 4.45, 5.35, $2.91 \%$ more than Zeolite in 4, 6, 15, 20 and $40 \mathrm{mg} \mathrm{L}^{-1}$, respectively.

\section{Conclusions}

The results shows that:

1. The maximum removal efficiency was $99 \%$ in 1000 $\mathrm{mg} \mathrm{L}^{-1}$ by Ambelite for $\mathrm{Pb}$.

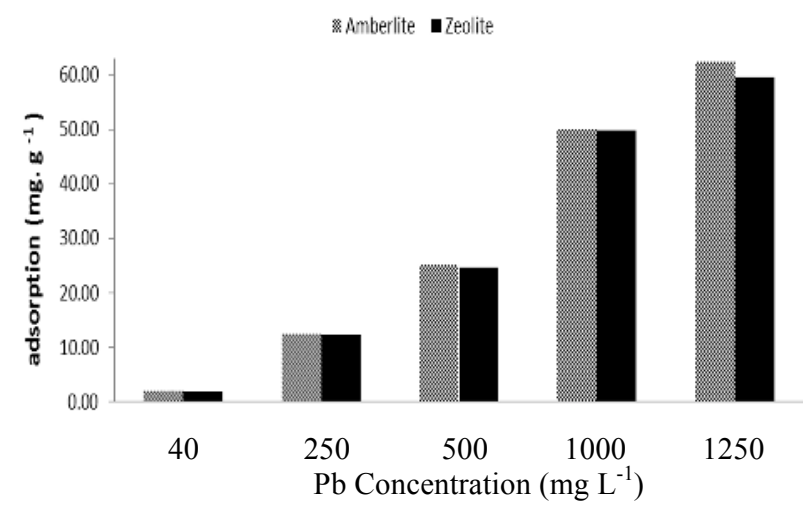

Fig. 3. Comparsion of Amberlite and zeolite in absorption of $\mathrm{Pb}$.

2. The minimum removal efficiency of $\mathrm{Pb}$ was $88.99 \%$ in $40 \mathrm{mg} \mathrm{L}^{-1}$ by Zeolite.

3. The absorption of $\mathrm{Pb}$ by Amberlite was found to be more than Zeolite.

4. The absorption of $\mathrm{Pb}$ by Amberlite was 9, 2.2, 0.97, $0.06,4.3,3.61 \%$ more than Zeolite in $40,250,500$, 1000 and $1250 \mathrm{mg} \mathrm{L}^{-1}$, respectively.

\section{Acknowledgements}

We hereby, we thanks Deputy of Research and Postgraduate Studies of Shahrekord University that undertook the expense of this study. Also, we thanks the Water Engineering Department of Shiraz University for providing the laboratory and the required facilities.

\section{References}

Alvarez-Ayuso E. Garcia-Sanchez A. X.Querol. Purification of metal. Water Research 2003 (37):4855-4862.

Chalesh Amiri, M. The principle of purification of water. Arkan publication. Tehran. 1982.

Demirbas A. Pehlivan E. Gode F. Altun T and Arslan G. Adsorption of $\mathrm{Cu}(\mathrm{II}), \mathrm{Zn}(\mathrm{II}), \mathrm{Ni}(\mathrm{II}), \mathrm{Pb}(\mathrm{II})$, and $\mathrm{Cd}(\mathrm{II})$ from aqueous solution on Amberlite IR-120 synthetic resin, Journal of Colloid and Interface Science 2005. 282:20-25.

Demirçivi P and Saygılı G. Removal of Boron from Waste waters by Ion- exchange in a batch System. World Academy of Science, Engineering and Technology 2008. 47.

Ghasem. Mobtaker, H. Kazemian, H. Malekinejad, A. zeinali, Danloo, A. A. Pakzad, S. M. Examining the usage of synthetic A and P-zeolite from natural zeolite clinoptilolite of iran for removing the heavy cations from simulated waste water, chemical absorption and chemical Engineering of Iran. 2005. 24(2)51-61.

Golabi H. The principle of separation chemistry. The method of separation. Second volume. Gangal puplication. Tehran. 1983. 
Hui K. Chai $\mathrm{H}$ and Kot S. Removal of mixed heavy metal ions in wastewater by zeolite $4 \mathrm{~A}$ and residual products from recycled coal fly ash. Journal of Hazardous Materials 2005. B127:89101.

Kabiri, K. Super-absorptive hydrogel introduction and usage, forth educational course and specialize seminar of agricultural usage of super-absortive hydrogels. 2010.

KumarJha M. Van Nguyen N. Lee J. Jeong J and Yoo J. Adsorption of copper from the sulphate solution of low copper contents using the cationic resin Amberlite IR 120. Journal of Hazardous Materials 2009. 164:948-953.

Liyuan W. Study on adsorption mechanism of $\mathrm{Pb}(\mathrm{II})$ and $\mathrm{Cu}(\mathrm{II})$ in aqueous solution using PS-EDTA resin. Chemical Engineering Journal 2010. 163. 364-372

Rahmani, H.Ghandi, A. Examinig the quality of waste water of metal meting company of Isfahan and its effects on soil, water, vegtables of agricultural land, ninth congress of soil sciences of Iran. 2005.

Rashad M. Selim M.E. Faiz F and Assaad. Removal of some heavy metal ions from aqueous solutions by linde- zeolite: Adsorption and kinetic study. Sixteenth International Water Technology Conference, IWTC 16, Istanbul, Turkey 2012.

Sprynskyy, M. Solid-liquid-solid extraction of heavy metals $(\mathrm{Cr}, \mathrm{Cu}, \mathrm{Cd}, \mathrm{Ni}$ and $\mathrm{Pb})$ in aqueous systems of zeolite-sewage sludge. Journal of Hazardous Materials 2009. 161:1377-1383.

Tabatabaei, S.H and Liaghat, A. Use of zeolite to control heavy metal municipal wastewater applied for irrigation. J. Ion Exchange. 2004.15(2):1-7.

Wadu,T and Okamura,E. The ion-exchange reactions on clinoptilolite. 4th International Conference on the Fundamental and Applied Aspects of Physical Chemistry. 1998. 621-623. 